\title{
The Effect of Creative Arts Therapy on Stress Level and Blood Pressure of The Elderly With Hypertension
}

\author{
Putu Ayu Sani Utami ${ }^{1}$, Ni Made Dian Sulistiowati ${ }^{2}$, Putu Ayu Emmy Savitri Karin ${ }^{3}$ \\ Nursing Study Program \\ Faculty of Medicine, Udayana University \\ Denpasar, Bali \\ putuayusani@gmail.com \\ Nursing Study Program \\ Faculty of Medicine, Udayana University \\ Denpasar, Bali \\ Nursing Study Program \\ Faculty of Medicine, Udayana University \\ Denpasar, Bali
}

\begin{abstract}
The elderly are vulnerable to hypertension due to the accumulation of unhealthy lifestyles for a long time and can be exacerbated by the stress due to the inability to adapt to the decline in physical conditions, changes in roles and social relations, economic ability, degenerative diseases and treatment in the long term. Risk factors for hypertension can caused by stress. Stress management can be done with a combination of creative arts therapy that is singing, drawing, and storytelling which has a relaxing effect. This study aims to determine the effect of creative arts therapy on stress levels and blood pressure of the elderly with hypertension in Kesiman Kertalangu Village, East Denpasar City, Bali, Indonesia. This research was a quasy experiment with pre-test and post-test design. Samples used were 63 elderly with hypertension who experience mild and moderate stress using simple random sampling technique divided into three groups of treatment with the amount 21 elderly of each groups. Stres level of of hypertension were evaluated using The Stress Assessment Questionnaire and blood pressure measurement using manometer. The main results of this study indicated that creative art therapy can reduce stress of the elderly significantly with $p$ value $0.000<0.05$. An average of blood pressure in creative art therapy has decreased. Wilcoxon test results showed the $p$ value of blood pressure (sistole;diastole) for singing $(0.002 ; 0.014)$, storytelling $(0.009 ; 0.008)$ and drawing $(0.016 ; 0.011)<0.05$ which means that there is an effect of those therapy on elderly blood pressure. The results of the Ancova analysis showed no difference in blood pressure results after each intervention was given to the elderly ( $p$ value $0.244>0.05$ for systole dan $p$ value $0.738>0.05$ for diastole). That means that each intervention has a similar effect on reducing blood pressure. Creative arts therapy provides a relaxing effect while performing art activities so that feeling calms down and stimulates the healing process. Further research with a larger population needs to be done to increase public awareness of the benefits of creative art therapy to reduce stress and blood pressure in the elderly with hypertension.
\end{abstract}

\section{Index Terms - : elderly, creative arts therapy, singing, drawing, story telling, hypertension}

\section{INTRODUCTION}

The elderly are vulnerable to experiencing health problems due to the decline in body functions physiologically especially degenerative diseases. Degenerative diseases that often occur in the elderly due to the aging process is hypertension [1]. The prevalence of hypertension in elderly is already increase from year to year. Risk factors for hypertension can caused by stress and activity physical goddess. There is a relationship of stress with events hypertension in elderly, where equal to $63,55 \%$ elderly hypertension experience stress [2]. The threat or demands that can not be overcome can interfere with one's psychological well-being [3].

The prevalence of emotional mental disorders in Indonesia at $11.6 \%$. Emotional mental disorders are

more prevalent in urban areas than in the villages [4]. The highest prevalence of emotional mental disorders by 
group age occurs at age 65 years and over. Besides causing mental problems, stress also causes problems in physical function such as headaches, muscle pain, joint pain, digestive disorders, and heart problems [5].

Stress management can be divided into pharmacological therapy with drugs, and nonpharmacology with distraction, as well as relaxation [6]. However, non-pharmacological stress management is preferred over because there is no serious side effect, especially relaxation therapy. Relaxation therapy that can developed to resolve stress is art therapy. Art therapy is an intervention that supports mental health, facilitated by art therapists which uses the media of art, the creative process, and the artwork that it produces for exploring client feelings, reducing anxiety, and increasing self-esteem [7]. Type of art therapy that is able to develop creativity and comfort is a creative arts therapy that includes therapy singing, drawing therapy and storytelling therapy.

Singing therapy is a form of art activity to express the mind and feeling through the tone of voice. The elderly who followed the singing therapy can more enjoy his life, able to perform daily physical activities and feel happier [8]. Singing therapy can improve the immune system and lower the hormone cortisol when the someone stressed [9][10][11]. Drawing as therapy can encourage individuals to create works of art that involve thought processes as well his feelings [12]. Every artwork creates more and more individual awareness develops on life experiences that are emotional reactions to every life event traversed, so it will be useful in increasing the potential of himself in preventing problems. Another case with storytelling therapy, it has an effect to stimulate emotions relaxation, develop morale to know good and bad deeds and increase motivation [13].

Unresolved stress can lead to more serious emotional problems, therefore need to be overcome. The management of stress by using creative arts therapy, involve the elements of elderly everyday life and the culture inherent in his life can facilitate the elderly to explore feelings and improve comfort. The aim of this study is to determine the effect of creative arts therapy on stress and blood pressure of elderly with hypertension in Kesiman Kertalangu Village, East Denpasar..

\section{METHOD}

This research was a quasy experiment with one group pre-test and post-test design. Samples was 63 elderly with hypertension in Kesiman Kertalangu Village with mild and moderate stress using simple random sampling technique divided into three treatment groups with 21 each other. Place of study in Kesiman Kertalangu Village, East Denpasar City, Bali, Indonesia. Selection of therapy in each group using randomization techniques. This area is used because the elderly have the same social demographic characteristics and there are one of the areas with the highest number of hypertension in Denpasar. Therapy is carried out every week in a month with 60 minutes of each session.

Data collection using blood pressure measurement observation sheets, Questionnaire Physical symptoms of stress National Safety Council and questionnaire Stress Assessment Questionnaire (SAQ). Univariate analysis was used in presenting data of respondent's characteristics. Wilcoxon test was used to determine the effect of creative arts therapy on stress and blood pressure because because the data is non parametric for stres level and the data not normally distributed for blood pressure (95\% confidence interval). Ethical Aspects include informed consent was obtained from all subjects. The protocol was approved by the University of Udayana/Sanglah Hospital Institutional Review Board.

\section{RESULT}

\section{A. Demographic Characteristic}

This study involved 63 respondents with ages ranging from 60-79 years, the majority of respondents were female at $71.4 \%$. Most respondents have an interest in one or all types of creative art therapy $(87.3 \%)$.

B. The effect of creative arts therapy on the level of stress of the elderly

TABLE I

THE EFFECT OF CREATIVE ARTS THERAPY ON THE LEVEL OF STRESS $(\mathrm{N}=63$

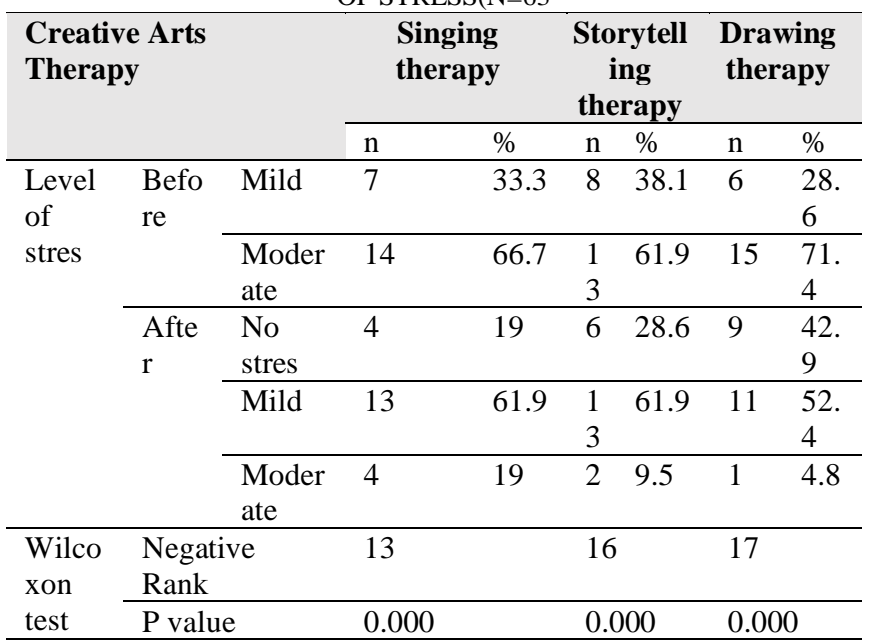

Table 1 showed the effect of creative arts therapy (singing, storytelling and drawing) on the level of stress of the elderly with hypertension. Creative art therapy can reduce stress of the elderly significantly with $\mathrm{p}$ value $0.000<0.05$.

\section{The effect of creative arts therapy on the blood pressure of the elderly}

Normality test with Shapiro Wilk shows the data not normally distributed where the $\mathrm{p}$ value $<0.05$. Therefore blood pressure data were analyzed by Wilcoxon test. 
TABLE II

THE EFFECT OF CREATIVE ARTS THERAPY ON BLOOD PRESSURE $(\mathrm{N}=63)$

\begin{tabular}{|c|c|c|c|c|}
\hline \multirow{3}{*}{$\begin{array}{l}\text { Creative Arts } \\
\text { Therapy } \\
\text { Blood } \\
\text { Pressure }\end{array}$} & \multicolumn{4}{|c|}{ Singing therapy } \\
\hline & \multicolumn{2}{|c|}{ Sistole (mmHg) } & \multicolumn{2}{|c|}{ Diastole (mmHg) } \\
\hline & Pretest & Post test & Pretest & Post test \\
\hline Mean & 158.10 & 150.95 & 88.10 & 83.81 \\
\hline SD & 11.23 & 7.68 & 6.79 & 6.69 \\
\hline $95 \% \mathrm{Cl}$ & $\begin{array}{l}152.98- \\
163.21\end{array}$ & $\begin{array}{l}147.45- \\
154.45\end{array}$ & $85.00-91.19$ & $\begin{array}{l}80.76- \\
86.85\end{array}$ \\
\hline Negative Rank & 11 & & 7 & \\
\hline \multirow[t]{2}{*}{ P Value } & 0.002 & & 0.014 & \\
\hline & \multicolumn{4}{|c|}{ Storytelling therapy } \\
\hline Blood & \multicolumn{2}{|c|}{ Sistole (mmHg) } & \multicolumn{2}{|c|}{ Diastole (mmHg) } \\
\hline Pressure & Pretest & Post test & Pretest & Post test \\
\hline Mean & 160.95 & 155.71 & 88.10 & 84.76 \\
\hline SD & 11.79 & 10.28 & 7.49 & 5.12 \\
\hline $95 \% \mathrm{Cl}$ & $\begin{array}{l}155.58- \\
166.32\end{array}$ & $\begin{array}{l}151.03- \\
160.39\end{array}$ & $84.68-91.51$ & $\begin{array}{l}82.43- \\
87.09\end{array}$ \\
\hline Negative Rank & 8 & & 7 & \\
\hline \multirow[t]{2}{*}{ P Value } & 0.009 & & 0.008 & \\
\hline & \multicolumn{4}{|c|}{ Drawing therapy } \\
\hline \multirow{2}{*}{$\begin{array}{l}\text { Blood } \\
\text { Pressure }\end{array}$} & \multicolumn{2}{|c|}{ Sistole (mmHg) } & \multicolumn{2}{|c|}{ Diastole (mmHg) } \\
\hline & Pretest & Post test & Pretest & Post test \\
\hline Mean & 160.00 & 154.76 & 89.05 & 85.24 \\
\hline SD & 12.25 & 9.81 & 7.00 & 5.11 \\
\hline $95 \% \mathrm{Cl}$ & $\begin{array}{l}154.43- \\
165.57\end{array}$ & $\begin{array}{l}150.30- \\
159.23\end{array}$ & $85.86-92.24$ & $\begin{array}{l}82.91- \\
87.57\end{array}$ \\
\hline Negative Rank & 7 & & 7 & \\
\hline P Value & 0.016 & & 0.011 & \\
\hline
\end{tabular}

Table 2 shows an average blood pressure in creative art therapy has decreased. The results of the Ancova analysis showed no difference in blood pressure results after each intervention was given to the elderly ( $\mathrm{p}$ value $0.244>0.05$ for systole dan $\mathrm{p}$ value $0.738>0.05$ for diastole). That means that each intervention has a similar effect on reducing blood pressure. In addition, covariate interest in art does not contribute to a decrease in blood pressure with $\mathrm{p}$ value $0.890>0.05$.

\section{RESULT}

A. The effect of singing therapy on stress level and blood pressure of elderly with hypertension.

The results obtained physical symptoms of stress that many experienced in elderly are pain in joints $(52.4 \%)$, tension headaches $(42.9 \%)$ and tension in the neck muscles and shoulder $(38.1 \%)$. Frequency of stress level of elderly who get singing therapy were decrease. Before therapy, stress level showed in moderate and mild levels, but after singing therapy there are $19 \%$ elderly people not stressed. Statistical test results obtained p value $0.000<0.05$ which means there is the effect of singing therapy on the elderly stress level with hypertension. Singing has an excellent benefit for psychological and psychological health somebody. By singing, the feelings will become expressed, became more relieved, and more enthusiastic [9].

The blood pressure average of the elderly after therapy has decreased, where systolic blood pressure decreases by
$7.15 \mathrm{mmHg}$ and diastolic blood pressure decreases by 4.29 $\mathrm{mmHg}$. Statistical test results showed the $\mathrm{p}$ value of systolic (0.002) and diastolic (0.014) blood pressure $<0.05$, which means that there is an effect of singing therapy on elderly blood pressure. Singing is stimulating and lowered the stress level through the work of our body's endocrine system [10]. In this study, songs that are sung by older people are songs that have meaning in their feelings. It is better to sing songs that bring out happiness so that it can cause a sense of comfort. The type of music and the beat don't matter as long as the elderly feel happy. Singing is able to make feelings more comfort and relax because the release of endorphins throughout the body when we sing [11].

B. The effect of story telling therapy on stress level and blood pressure of elderly with hypertension.

Physical symptoms of stress experienced by many older are tense in neck and shoulder muscles (42.9\%), joint pain $(23.8 \%)$, and abdominal pain (19\%). Frequency of stress level of elderly who get the storytelling therapy are decreased. After the storytelling therapy there are $28.6 \%$ elderly who not experiencing stress. Statistical test results obtained $\mathrm{p}$ value $0.000<0.05$ which means there the effect of storytelling therapy on stress level of the elderly with hypertension. These results are in accordance with previous studies where storytelling therapy has an effect on the level of depression in the elderly with $\mathrm{p}$ value $0.000<0.05$ [23]. The blood pressure average of the elderly after therapy has decreased, where systolic blood pressure decreases by 5.24 $\mathrm{mmHg}$ and diastolic blood pressure decreases by 3.34 $\mathrm{mmHg}$. Statistical test results showed the $\mathrm{p}$ value of systolic (0.009) and diastolic (0.008) blood pressure<0.05, which means that there is an effect of storytelling therapy on elderly blood pressure.

In this study, the elderly were invited to listen to folklore and tell stories. After that, they were asked to look for the meaning of the story that was told. In this storytelling therapy, the elderly are invited to develop imagination and listening skills. Storytelling therapy is useful to stimulate emotion [14]. Storytelling has the power to encourage openness because it involves imagination and emotion and the development of cognitive, affective, social, and spek aspects conative [15]. Listening and telling stories helps individuals understand themselves and others [16]. Storytelling therapy provide benefits for value planting, increase in motivation behave, and train the power of concentration and develop positive emotions [14]. Giving storytelling therapy for elderly can develop emotions and psychological conditions becomes more positive [17]. Submission of information through the storyline making the elderly easier to understand the moral role that contained in each story to motivate the elderly enjoying his old age with calm and prosperous.

C. The effect of drawing therapy on stress level and blood pressure of elderly with hypertension.

The results obtained physical symptoms of stress 
experienced by many older are tense in the neck and shoulder muscles (42.9\%), abdominal pain (33.3\%), tension headache, joint pain and diarrhea respectively $28.6 \%$ ). Frequency of elderly stress levels get drawing treatment has decreased where before given therapy. After drawing therapy there were $42.9 \%$ of elderly who did not experience stress. Test results statistics obtained $\mathrm{p}$ value $0.000<0.05$ which means there is effect of drawing therapy against the elderly stress level with hypertension. These results are in accordance with previous studies where drawing therapy has an effect on the elderly stress level with $\mathrm{p}$ value $0.001<0.05$ [24]. In addition, the blood pressure average of the elderly after therapy has decreased, where systolic blood pressure decreases by $5.24 \mathrm{mmHg}$ and diastolic blood pressure decreases by $3.81 \mathrm{mmHg}$. Statistical test results showed the $\mathrm{p}$ value of systolic $(0.016)$ and diastolic $(0.011)$ blood pressure $<0.05$, which means that there is an effect of drawing therapy on elderly blood pressure.

Art therapy in the form of drawing gives creative expression to someone. Creative expressions help overcome personal, especially psychological, limitations that help one to express feelings that can not be conveyed verbally, increasing trust, problem-solving abilities greater, less anxiety, and the ability to form oneself active [18]. Drawing therapy also has other benefits, namely as a media of imagination; as a media of emotional arrangement where therapy draws provide a multisensory experience in the creation of artwork that can improve memory, feeling free, and increase activity levels [19]; as media of life review; and as media of recreational activity [20].

In this study the elderly were asked to draw and color the mandala. Drawing and coloring mandalas can be an effective physiological stress reducer for individuals with intellectual and stress problems that can be measured from changes in systolic, diastolic, and pulse blood pressure [25].

Drawing therapy is a therapy that uses images as natural communication in expressing feelings and thoughts. The subject is drawing a realistic look in everyday life or a picture emphasize image style [21]. Drawing can be given on clients with various problems, such as someone who is under pressure, work stress, children and adolescents who have difficulty learning and experiencing problems emotional, elderly people who experience stress as a means of expressing feelings, ideas, and emotions, adults who are unable or unwilling to speak about thoughts and feelings, patients with schizophrenia, as well as patients who experience autism, and dementia [7][18].

Finally, the results showed a decrease in stress levels in the majority of respondents namely 46 person (73\%). Creative arts therapies such as singing, storytelling and drawing help to inflict feeling comfortable or relaxed. In a state of relax, the body through the brain will produce endorphrin which functions as body's natural analgesics and can relieve pain (physical complaints). In addition, in a relaxed state of the body will activate the parasympathetic nervous system which functions to decrease heart rate, respiratory rate and blood pressure [22].

\section{CONCLUSION}

This study found that the majority of the elderly were experience decreased levels of stress and blood pressure. Creative arts therapy provides a relaxing effect while performing art activities so that feeling calms down and stimulates the healing process. As a creative arts therapy, singing, storytelling and drawing can facilitate the client to express internal feelings. The art products produced can reflect the internal capabilities and conflicts experienced by the elderly.

\section{ACKNOWLEGDMENT}

The Author would like to acknowledge financial support for this study in the form of grants Non-Tax State Revenue (PNBP) from Udayana University, Bali year 2016.

\section{REFERENCES}

[1] Ministry of Health of the Republic of Indonesia. "Elderly Situation and Analysis, (online) “(http://www.depkes.go.id/resources/download/pusdatin/infodatin/inf odatin-lansia.pdf, accessed August 5, 2015). 2014.

[2] Adria, K.M. "Relationship Between Sports Behavior, Stress And Eating Diet With Hypertension Level At Elderly At Elderly Posyandu Kelurahan Gebang. White District Sukolilo Surabaya City". Journal of Health Promotion, Vol. 1, No. 2, 111-117. 2013.

[3] Astri, K. "Manajemen Stres dan Kesepian dengan Multicomponent Cognitive Behavioral Group Therapy (MCBGT) pada Lansia. Tesis (diterbitkan)". Depok: Fakultas Psikologi Universitas Indonesia. 2012.

[4] Basic Health Research. "Basic Health Research. Jakarta: Indonesian Ministry of Health's Health Research and Development Agency". 2013.

[5] Ministry of Health of the Republic of Indonesia. "Technical Guidelines for Finding and Management of Hypertension". Jakarta: Ministry of Health Republic of Indonesia. 2006.

[6] Potter, P.A . Perry, A.G. "Fundamental of Nursing". Jakarta: Salemba Medika 2012.

[7] American Art Therapy Association. "Art Therapy", (online). (http://www.arttherapy.org/upload/whatisarttherapy.pdf, diakses 21 Agustus 2015). 2013.

[8] Cassol, M, \& Bos, A.J.G. "Impact of Choir Singing in Elderly on Depression Symptoms and Voice Quality". Public Health and Preventive Medicine. Vol. 1, No. 3, 2015, pp. 101-107 http://www.aiscience.org/journal/phpm diakses 20 Februari 2016). 2015.

[9] Beck, R.J., Cesari, T.C., Yousefi, A. \& Enamoto, H. "Choral singing, performance perception, and immune system changes in salivary immunoglobulin A and cortisol, Music Perception”, 18(1), 87-106. 2000.

[10] Kuhn,D. "The effects of active and passive participation in musical activity on the immune system as measured by salivary immunoglobulin A (SigA)". Journal of Music Therapy. 39(1), 30-39. 2002.

[11] Kreutz, G., Bongard, S., Rohrmann, S., Grebe, D., Bastian, H.G. \& Hodapp, V. "Effects of choir singing or listening on secretory immunoglobulin A, cortisol and emotional state". Journal of Behavioral Medicine. 27(6), 623635. 2004.

[12] Wylie, B. "Self And Social Function: Art Therapy In A Therapeutic Community Prison". Brand Management, 14, 324-334. 2007.

[13] Qudsyi. H. "Optimalisasi Metode Bercerita (Story Telling) Dalam Pendidikan Tauhid Pada Anak". Program Studi Psikologi Universitas Islam Indonesia, (Online). From: http://data.dppm.uii.ac.id. Diakses pada 5 Oktober 2015. 2011.

[14] Asfandiyar, A.Y. "Cara Pintar Mendongeng". Bandung: Mizan Pustaka. 2007.

[15] Hilder, M. "The Enemy's gospel: Deconstructing Exclusivity and inventing Inclusivity through the power of story". Journal of Curriculum and Supervision 20(2), 158-181. 2005. 
[16] Bishop, K. Kimball, M. "Engaging Students in Storytelling". Teacher Librarian, 33(4), 31-38. 2006.

[17] Kusumastuti, D.N. "Pengaruh Kegiatan Storytelling terhadap Pertumbuhan Minat Baca Siswa di TK. Bangun 1 Getas Kecamatan Pebelan Kabupaten Semarang". Skripsi dipublikasikan. Semarang: Fakultas Ilmu Budaya Universitas Diponegoro. 2010.

[18] Fatmawati, A. "Kajian Literatur: Efektifitas Art Therapy dalam Meningkatkan Kualitas Hidup dan Kesehatan Psikologis Pasien Penyakit Ginjal Kronik yang Menjalani Hemodialisis”. Jurnal Medica Majapahit, Vol. 7, No. 1, 1-10. 2015.

[19] Johnson, C., \& Sullivan-Marx, E. "Art Therapy Using The Cre $a$ ative Process For Healing And Hope Among African American Older Adults". Geriatric Nursing, Vol. 5, No. 23, 309-316. 2006.

[20] Martin, N. "Art As An Early Intervention Tool For Children With Autism". London: Jessica Kingsley Publisher. 2009.

[21] Malchiodi, C.A. "Art Therapy and Health Care". New York: Guilford Press. 2013.

[22] Sulistyarini, I. "Terapi Relaksasi untuk Menurunkan Tekanan Darah dan Meningkatkan Kualitas Hidup Penderita Hipertensi." JURNAL PSIKOLOGI VOLUME 40, NO. 1, JUNI 2013: 28 - 38. 2013.

[23] Putri, N.M.G.A.N.,Utami, P.A.S., Wijaya, A.A.N.T. "Pengaruh Terapi Bercerita Terhadap Tingkat Depresi Lansia". Coping: Community Of Publishing In Nursing, [S.L.], V. 7, N. 1, P. 7-12, Apr. 2019. ISSN 2303-1298. Available at .https://ojs.unud.ac.id. 2019.

[24] Setiana, D.G.A.A.S., Wiyani, C., Erwanto, R. "Pengaruh Art Therapy (Terapi Menggambar) Terhadap Stres Pada Lansia. Jurnal Kebidanan Dan Keperawatan”, Vol. 13, No. 2, Desember 2017: 192202. 2017.

[25] Schrade, C., Tronsky, L., and Kaiser, D.H. "The Art in Psychotherapy: Physiological Effect of Mandala Making in Adult With Intellectual Disability". Elsevier. United States: The Kennedy Centre,Trumbull, CT, and Albertus Magnus College, New Haven, CT. 2011. 